\section{Geophysicists accused of breach of publishing ethics}

Scientists at the Institute of Geophysics in Paris (IPGP) have been accused of acting as editors for dozens of papers by IPGP colleagues published from 1992 to 2008 in the journal Earth and Planetary Science Letters while they were members of the editorial board. The allegations follow a joint investigation by science journalists at the French newspapers Le Monde and Libération.

Among the authors of the articles involved is Claude Allègre, a former research and education minister in the French government and former IPGP head, whom French President Nicolas Sarkozy has been rumoured to be wooing to take up a ministerial position; and Vincent Courtillot, the institute's current head and a member of the journal's editorial board from 2003 to 2005.

Courtillot has dismissed the allegations, pointing out in Le Monde that all editors of papers submitted to the journal by the IPGP were openly identified. Allègre has described the allegations as "ridiculous". But Friso Veenstra, publisher of the Elsevier journal, maintains that reviewing papers from one's own institution runs against the journal's ethics policy.

\section{UK revises visa rules to help visiting scientists}

The UK government is to reform aspects of immigration rules implemented in November 2008, after universities warned that the system would prevent up to 2,000 overseas researchers a year from entering the country. Previously, overseas academics coming to the United Kingdom to carry out research for two to three years could enter the country on a 'sponsored researcher visa'. But under the new points-based immigration system, the visa was scrapped, leaving researchers with no clear entry route. Researchers will now be included under a 'tier 5 ' entry route, reserved for sponsored temporary workers.

\section{US National Academies suspend visits to Iran}

The US National Academies are advising American scientists to avoid travelling to Iran, following the detention in December of one of the academies' top officials.

Glenn Schweitzer, a veteran physicist who manages scientific visits and exchanges in Eurasia for the National Academy of Sciences, was in Iran as part of a longrunning programme between the academy

\title{
Dinosaur graveyard promises clues to extinction
}

More than 7,600 fossilized dinosaur bones have been unearthed since March 2008 at what Chinese palaeontologists now claim is the largest dinosaur graveyard in the world.

Most of the bones date back to the Late Cretaceous period more than 100 million years ago, raising speculation that the finds could offer clues about why the creatures died out. The discoveries, made by researchers from the Chinese Academy of Sciences, include bones from what might be the

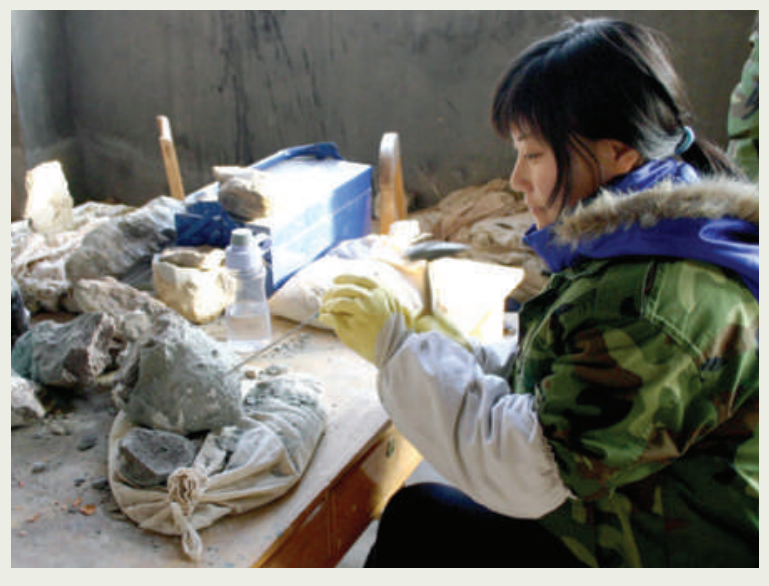

largest duck-billed dinosaur discovered to date. The site consists of 15 separate areas in Zhucheng, Shandong province, which has yielded more than 50 tonnes of dinosaur bones since the 1960 s.

and Iranian scientific organizations. The programme promotes collaboration and aims to keep scientific diplomatic channels open between the two countries despite the continuing political confrontation.

Schweitzer was detained on two occasions by three men claiming to be from the Iranian security services, who threatened to prevent him from leaving the country if he did not cooperate, he says. The academies say that visits will resume only if the Iranian government provides firm assurances that US scientists can visit the country safely. For a longer version of this story, see http://tinyurl.com/7ajyfc.

\section{California sues in bid to preserve wildlife laws}

The state of California has filed a lawsuit against the US government to block recent changes to the Endangered Species Act that conservationists say threaten animals and their habitats.

The changes to the act, finalized by the Bush administration on 16 December 2008, allow federal agencies to undertake commercial activities, such as logging and

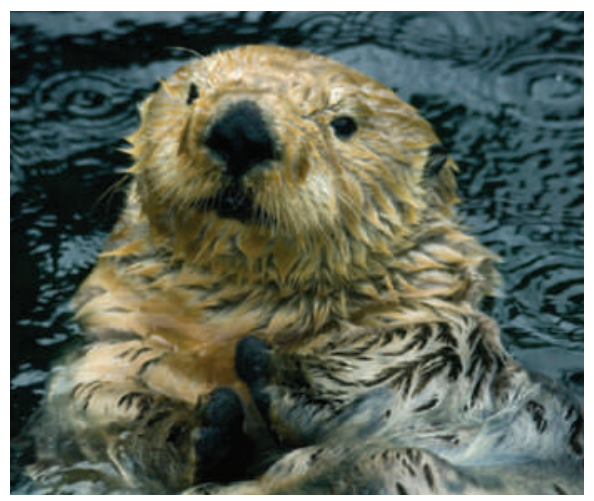

The sea otter may be adversely affected by changes to the US Endangered Species Act. mining, without getting external wildlife biologists to assess the environmental consequences of new projects. The rules also bypass the need to consider the effects of greenhouse gases on species and ecosystems.

Three US environmental groups - the Natural Resources Defense Council, the National Wildlife Federation and the Center for Biological Diversity - have filed similar lawsuits. President-elect Barack Obama has said that he opposes the last-minute changes to the act.

\section{Nigeria finally appoints its health ministers}

Nine months after the health minister and a minister of state resigned over corruption charges, the Nigerian government has at last filled the vacant posts.

Pathologist Babatunde Osotimehin, who until last month was the director-general of Nigeria's National Agency for the Control of AIDS, was sworn in on 17 December 2008 as health minister alongside his new minister of state, Aliyu Idi Hong. Osotimehin told Nature that he sees research into infectious diseases as a priority for the country.

Former minister Adenike Grange and her minister of state, Gabriel Aduku, stepped down after a plot to share $\mathbf{3 0 0}$ million Nigerian naira (US\$2.2 million) from the ministry's 2007 budget among staff was leaked to the country's anticorruption watchdog. The two, together with more than ten other officials, are now on trial facing 56 counts of fraud between them.

\section{Correction}

The reference list and citations in the News Feature 'Let's make a mammoth' (Nature 456, 310-314; 2008) are in the incorrect order. The $\mathrm{html}$ version of this article has been amended to give the correct citations, and a corrected PDF can be downloaded from http://tinyurl.com/86hmp2. 